\section{Plant Spatial Arrangement Affects Growth, Yield, and Pod Distribution of Cayenne Peppers}

\author{
Dennis R. Decoteau and Heather A. Hatt Graham ${ }^{1}$ \\ Department of Horticulture, Poole Agricultural Center, Box 340375, Clemson \\ University, Clemson, SC 29634-0375
}

Additional index words. Capsicum annuum, planting population density, in-row spacing, rows per bed

\begin{abstract}
The effect of planting population density (as a function of in-row plant spacing and number of rows per bed) on the growth, yield, and pod distribution of cayenne pepper (Capsicum annuum var. annuum L. Cv. Carolina Cayenne) was investigated in a 2-year study. In 1988, $15-, 30-, 45-$, and 60-cm in-row spacings in a single row were evaluated, and in $198915-, 30-$, and $60-\mathrm{cm}$ in-row spacings in single and double rows were evaluated. Plant population densities at these respective spacings ranged from $\approx 11,100$ to 44,400 and 11,100 to 88,900 plants/ha. In 1988 , pepper plants grown at the highest density $(15-\mathrm{cm}$ in-row spacing, 44,400 plant/ha) produced less fruit per plant but more fruit per hectare than those grown in lower densities. In 1989, yields with either a 15-cm in-row spacing in a single row or a $30-\mathrm{cm}$ in-row spacing in double rows (both with 44,400 plants/ha) were higher than in the others. In general, less fruit were located in the lower part of the plant canopy when planted in higher plant population densities.
\end{abstract}

The use of hot peppers (e.g., cayenne, jalapeno, habanero) in meal preparation is increasing in popularity in the United States (South, 1992). In the southeastern United States, hot pepper acreage has increased, and this crop may be an alternative, higher value cash crop than the currently produced vegetable and field crops (Johnson and Johnson, 1992). To reduce labor costs and increase production efficiency, mechanized harvesting has been evaluated for peppers (Kovalchuck, 1983; Marshall, 1984; Sundstrom et al., 1984; Wolf and Alper, 1984). An on-site evaluation of a modified bean harvester for harvesting cayenne pepper in South Carolina suggested that only $\approx 50 \%$ to $70 \%$ of the pepper fruit were mechanically harvested and collected. A high percentage of the nonharvested marketable fruit was from the lower part of the plant canopy.

Cultural factors, such as transplant age (McCraw and Greig, 1986; Weston, 1988), geographical location of transplant production (Weston, 1988), pruning (McCraw and

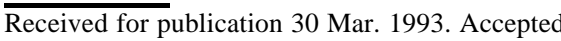
for publication 7 Sept. 1993. Technical contribution no. 3399 of the South Carolina Agricultural Experiment Station. This research was supported in part by Experiment Station Project no. 1187 and a U.S. Dept. of Agriculture Special Grant P.L. 89-106. Mention of a trademark or proprietary product does not imply its approval or endorsement by Clemson Univ. or the South Carolina Experiment Station to the exclusion of other products that maybe suitable. The cost of publishing this paper was defrayed in part by the payment of page charges. Under postal regulations, this paper therefore must be hereby marked advertisement solely to indicate this fact.

'Current address: Plant Sciences Dept., New Mexico State Univ., Las Cruces, NM 88003.
'Carolina Cayenne' pepper was used in both experiments. Field plots were located at the Clemson Univ. Calhoun Field Site, Clemson, S.C. The soil was a Congaree silt loam (Typic Paleudults). Fertilizer was applied before planting at N, P, and Krates of 56, 112 , and $112 \mathrm{~kg} \cdot \mathrm{ha}^{-1}$, respectively, and disked into the top $0.2 \mathrm{~m}$ of soil.

Seeds were sown on 28 Apr. 1988 and 31 Apr. 1989 in seedling trays (Speedling, Sun City, Fla.) (4.5-cm cell length, $\left.39 \mathrm{~cm}^{3}\right)$ using a commercial potting mix (Fafard Soilless Peat Mix no. 3, Anderson, S. C.) and placed in a greenhouse. Seedlings were transplanted to the plots on 30 May 1988 and 25 May 1989. Recommended cultural practices for peppers (Cook et al., 1982) were followed throughout these studies. Overhead irrigation was applied as needed to supplement rainfall. Plants were harvested by hand on 2 Nov. 1988 and 12 Oct. 1989. The harvest was delayed in 1988 because cool weather during October retarded fruit ripening on the plants. A single harvest was used each year to simulate a destructive mechanical harvest.

At harvest, plant growth measurements recorded from four random plants within each plot included stem diameter (measured at the base of the stem at the soil surface with a caliper), plant height from soil surface to apical bud, maximum plant width (determined by looking downward through the plant canopy), and plant dry weight. Location of fruit distribution within the canopy was determined by segregating fruit according to a horizontal level within the canopy. Plant levels were measured and designated from the ground upward: $1=$ soil surface to $15 \mathrm{~cm}$ upward, $2=$ 15 to $30 \mathrm{~cm}, 3=30$ to $45 \mathrm{~cm}, 4=45$ to $60 \mathrm{~cm}$, $5=60$ to $75 \mathrm{~cm}, 6=75$ to $90 \mathrm{~cm}, 7=90$ to 105 $\mathrm{cm}$. Fruit were separated according to color (red or green), counted, and weighed. Results were tested by analysis of variance. Regression analysis was used to identify significant trends, and LSD values were calculated for use in pairwise comparison of treatment means.

\section{Results and Discussion}

1988. In-row plant spacing influenced cayenne pepper plant growth (Table 2). As in-row spacing increased from 15 to $60 \mathrm{~cm}$, plant dry

\section{Materials and Methods}

Two experiments were conducted to determine the effects of planting population density on cayenne pepper growth and production. In 1988, 15-, 30-, 45-, and 60-cm in-row spacings in single rows on a raised bed $(86 \mathrm{~cm}$ wide x $15 \mathrm{~cm}$ high) were evaluated; in 1989, 15-, $30-$, and $60-\mathrm{cm}$ in-row plant spacings in single and double rows (30 $\mathrm{cm}$ apart) on a raised bed were evaluated. Plots were $6.1 \mathrm{~m}$ long with 1.5 $\mathrm{m}$ between bed centers. Plant population densities at these spacings (as measured from row center to row center) ranged from $=11,100$ to 44,400 and 11,100 to 88,900 plants/ha in 1988 and 1989 , respectively (Table 1). A randomized complete-block design with four replications was used in both years.
Table 1. In-row plant spacing, number of rows per bed, and plant population density used in spatial arrangement experiments on cayenne pepper.

\begin{tabular}{lcc}
\hline $\begin{array}{l}\text { Plant spacing } \\
(\mathrm{cm})\end{array}$ & $\begin{array}{c}\text { Rows/bed } \\
\text { (no.) }\end{array}$ & $\begin{array}{c}\text { Plants/ha } \\
(1000 \mathrm{~s})\end{array}$ \\
\hline & 1988 & \\
15 & 1 & 44.4 \\
30 & 1 & 22.2 \\
45 & 1 & 16.7 \\
60 & 1 & 11.1 \\
& 1989 & \\
15 & 1 & 44.4 \\
30 & 1 & 22.2 \\
60 & 1 & 11.1 \\
15 & 2 & 88.9 \\
30 & 2 & 44.4 \\
60 & 2 & 22.2 \\
\hline
\end{tabular}


Table 2. Effect of in-row plant spacing on cayenne pepper plant growth characteristics and pod yield, 1988.

\begin{tabular}{|c|c|c|c|c|c|c|c|c|c|c|}
\hline \multirow{4}{*}{$\begin{array}{l}\text { In-row } \\
\text { spacing } \\
(\mathrm{cm})\end{array}$} & \multicolumn{4}{|c|}{ Plant growth characteristics } & & & & & & \\
\hline & \multirow{3}{*}{$\begin{array}{l}\text { Dry } \\
\text { wt } \\
\text { (g) }\end{array}$} & \multirow{3}{*}{$\begin{array}{l}\text { Stem } \\
\text { diam } \\
(\mathrm{cm})\end{array}$} & \multirow{3}{*}{$\begin{array}{c}\mathrm{Ht} \\
(\mathrm{cm})\end{array}$} & \multirow{3}{*}{$\begin{array}{c}\text { Width } \\
\text { (cm) }\end{array}$} & \multicolumn{6}{|c|}{ Pod yield } \\
\hline & & & & & \multicolumn{2}{|c|}{ Red } & \multicolumn{2}{|c|}{ Green } & \multicolumn{2}{|c|}{ Total } \\
\hline & & & & & (g/plant) & $\left(\mathrm{Mg} \cdot h \mathrm{a}^{-1}\right)$ & (g/plant) & $\left(\mathrm{Mg} \cdot h \mathrm{a}^{-1}\right)$ & (g/plant) & $\left({\left.\mathrm{Mg} \cdot h \mathrm{a}^{-1}\right)}^{-1}\right.$ \\
\hline 15 & 173 & 18.2 & 95.8 & 143.8 & 100 & 4.4 & 77 & 3.4 & 177 & 7.9 \\
\hline 30 & 257 & 23.5 & 85.8 & 144.8 & 140 & 3.1 & 132 & 2.9 & 273 & 6.1 \\
\hline 45 & 281 & 25.5 & 80.0 & 144.2 & 240 & 4.0 & 161 & 2.7 & 407 & 6.8 \\
\hline 60 & 312 & 24.5 & 71.0 & 132.5 & 305 & 3.3 & 209 & 2.3 & 514 & 5.7 \\
\hline Significance $^{z}$ & $\mathrm{~L}^{+*}$ & $\mathrm{~L}^{* *}$ & $\mathbf{L}^{* *}$ & $\mathrm{~L}^{* *}$ & $\mathrm{~L}^{* *}$ & $\mathrm{~L}^{*}, \mathrm{Q}^{*}$ & $\mathbf{L}^{* *}$ & $\mathrm{~L}^{*}$ & $\mathrm{~L}^{* *}$ & $\mathrm{~L}^{*}$ \\
\hline
\end{tabular}

${ }^{\mathrm{2}} \mathrm{L}=$ linear, $\mathrm{Q}=$ quadratic.

****Significant at $P \leq 0.05$ or 0.01 , respectively.

weight and stem diameter increased linearly, but plant height and width decreased linearly.

Fruit production was also affected by inrow plant spacing. As spacing increased from 15 to $60 \mathrm{~cm}$, the weight of red, green, and total fruit produced per plant increased linearly (Table 2). Red, green, and total fruit production per hectare decreased as in-row spacing increased.

Red-pod fresh weight distribution at all inrow plant spacings was not uniform among plant levels within the canopy (Fig. 1). This weight tended to be higher in the lower levels (1-3) and lower in the upper levels (4-7). Mean pod weight in level 2 was higher than that in levels 4-7 for the 15-, 30-, and 45-cm in-row spacing, and in levels 3-7 for the 60$\mathrm{cm}$ in-row spacing. The greatest difference in red-pod fresh weight between the bottom levels and upper levels was in the widest in-row plant spacing $(60 \mathrm{~cm})$, and the least difference in red-pod fresh weight was in the closest inrow spacing $(15 \mathrm{~cm})$. At the closer plant spacing, a smaller proportion of red-pod fresh weight was distributed in the bottom levels ( $1-$ 3 ) than in the upper plant levels (4-7) (data not shown).

1989. In-row plant spacing and number of rows per bed influenced plant development (Table 3). As plant spacing increased, dry weight, stem diameter, and plant width increased linearly. Number of rows per bed affected dry weight, stem diameter, and plant width. The highest plant dry weight and thickest stems were produced on plants in the widest $(60 \mathrm{~cm})$ in-row spacing and one row per bed $(11,100$ plants/ha). Plant dry weight and stem diameter were least on plants grown at the $15-\mathrm{cm}$ plant spacing with two rows per bed (88,800 plants/ha). As in-row plant spacing increased, plant height increased.

Red-pod and total pod yields were affected by the number of rows per bed and in-row plant spacing. As in-row plant spacing increased from 15 to $60 \mathrm{~cm}$, red-, green-, and total pod yield per plant increased linearly (Table 3$)$. As the number of rows per bed increased from one to two rows, red- and total pod yield per plant decreased. In-row plant spacing and number of rows per bed did not affect red- and total pod yield per hectare. Green-pod yield per hectare decreased linearly as in-row spacing increased, and it was significantly lower with two than one row per bed.

Red-pod fresh weight distribution varied among plant levels within the canopy (Fig. 2) for all in-row plant spacings and number of rows per bed. The highest total red-pod fresh weight was in level 2 for the $30-\mathrm{cm} /$ one-row, $60-\mathrm{cm} /$ one-row, and $30-\mathrm{cm} /$ two-row treatments. Total red-pod weight was higher in level 2 than in level 1 and 4 through 7 for the $15-\mathrm{cm} /$ two-row treatment. As in-row spacing decreased for either the one or two rows per bed, less total pod fresh weight was produced in lower canopy levels. As the number of rows increased from one to two in corresponding inrow plant spacings, less total red-pod fresh weight was produced in lower plant canopy levels.

In-row plant spacing significantly affected cayenne pepper plant growth and fruit production. In both years, narrower in-row plant spacings generally produced more dry weight per plant, and the plants were taller, had thin- ner stem diameters, and set fewer fruit per plant but more fruit per hectare (as extrapolated from our data) than those at the wider inrow plant spacings. Sundstrom et al. (1984) reported that red 'Tabasco' pepper yields per hectare and stem diameter decreased linearly as in-row spacing decreased from 81 to $10 \mathrm{~cm}$, and stem breakage was less in the $10-\mathrm{cm}$ plant spacing, presumably because the stems were less woody and more flexible. In our study, plants grown at the $15-\mathrm{cm}$ in-row spacing (44,400 plants/ha) set fewer fruit per plant in lower plant canopy levels. In 1988, $45 \%$ of the red fruit weight in the $15-\mathrm{cm}$ in-row plant spacing was located in the lowest two plant levels, while $74 \%$ of the red fruit weight in the $60-\mathrm{cm}$ in-row spacing $(11,100$ plants/ha) was located in the lowest two levels. Fewer red fruit in the bottom of the canopy likely would increase the probability of harvesting fruit mechanically.

The number of rows per bed affected cayenne pepper growth and fruit production. Plantings on two rows per bed at the corresponding in-row plant spacings tended to reduce dry mass per plant, stem diameter, and number of red and total fruit per plant relative to one row per bed. The number of rows per bed did not affect red or total pepper yield per hectare. In the double-row plantings, less fruit was present in lower canopy levels than at the corresponding single-row plantings. Doublerow plantings likely would also increase the probability of harvesting more fruit mechanically.

These results suggest that in-row plant spacing and number of rows per bed affect plant growth and fruit production and that

Table 3. Effect of in-row plant spacing and number of rows per bed on cayenne pepper plant growth characteristics and pod yield, 1989.

\begin{tabular}{|c|c|c|c|c|c|c|c|c|c|c|c|}
\hline \multirow{4}{*}{$\begin{array}{l}\text { In-row } \\
\text { spacing } \\
(\mathrm{cm})\end{array}$} & \multirow{4}{*}{$\begin{array}{c}\text { Rows/ } \\
\text { bed } \\
\text { (no.) }\end{array}$} & \multicolumn{4}{|c|}{ Plant growth characteristics } & & & & & & \\
\hline & & \multirow{3}{*}{$\begin{array}{l}\text { Dry } \\
\text { wt } \\
\text { (g) }\end{array}$} & \multirow{3}{*}{$\begin{array}{l}\text { Stem } \\
\text { diam } \\
(\mathrm{cm})\end{array}$} & \multirow{3}{*}{$\begin{array}{c}\mathrm{Ht} \\
(\mathrm{cm})\end{array}$} & \multirow{3}{*}{$\begin{array}{l}\text { Width } \\
(\mathrm{cm})\end{array}$} & \multicolumn{6}{|c|}{ Pod yield } \\
\hline & & & & & & & & \multicolumn{2}{|c|}{ Green } & \multicolumn{2}{|c|}{ Total } \\
\hline & & & & & & (g/plant) & $\left({\left.\mathrm{Mg} \cdot h \mathrm{a}^{-1}\right)}^{-1}\right.$ & (g/plant) & $\left({\left.\mathrm{Mg} \cdot h \mathrm{a}^{-1}\right)}\right.$ & (g/plant) & $\left(\mathrm{Mg} \mathrm{ha}^{-1}\right)$ \\
\hline 15 & 1 & 156 & 24 & 111 & 111 & 117 & 5.2 & 44 & 2.0 & 161 & 7.2 \\
\hline 30 & 1 & 265 & 29 & 89.3 & 122 & 198 & 4.4 & 99 & 2.2 & 297 & 6.6 \\
\hline 60 & 1 & 423 & 33 & 63.3 & 123 & 369 & 4.1 & 124 & 1.4 & 493 & 5.5 \\
\hline 15 & 2 & 74 & 21 & 67.0 & 65.0 & 53 & 4.7 & 35 & 3.1 & 89 & 7.9 \\
\hline 30 & 2 & 167 & 24 & 85.0 & 70.3 & 118 & 5.2 & 60 & 2.7 & 178 & 7.9 \\
\hline 60 & 2 & 287 & 29 & 79.7 & 123 & 174 & 3.9 & 104 & 2.3 & 278 & 6.2 \\
\hline \multicolumn{12}{|c|}{ Significance $^{z}$} \\
\hline \multicolumn{2}{|c|}{ Spacing (S) } & $\mathrm{L}^{* *}$ & $\mathrm{~L}^{* *}$ & $\mathbf{L}^{*}$ & $\mathrm{~L}^{* *}$ & $\mathrm{~L}^{* *}$ & NS & $\mathrm{L}^{* *}$ & $\mathbf{L}^{*}$ & $\mathrm{~L}^{* *}$ & NS \\
\hline \multicolumn{2}{|c|}{ Rows (R) } & $* *$ & $* *$ & NS & $* *$ & $* *$ & NS & NS & $*$ & $* *$ & NS \\
\hline \multicolumn{2}{|c|}{$\mathrm{R} \times \mathrm{S}$} & NS & NS & $* *$ & NS & NS & NS & NS & $\mathrm{NS}$ & NS & NS \\
\hline
\end{tabular}

${ }^{2} \mathrm{~L}=$ linear.

${ }^{\text {Ns }}$,,$* *$ Nonsignificant or significant at $P \leq 0.05$ or 0.01 , respectively. 


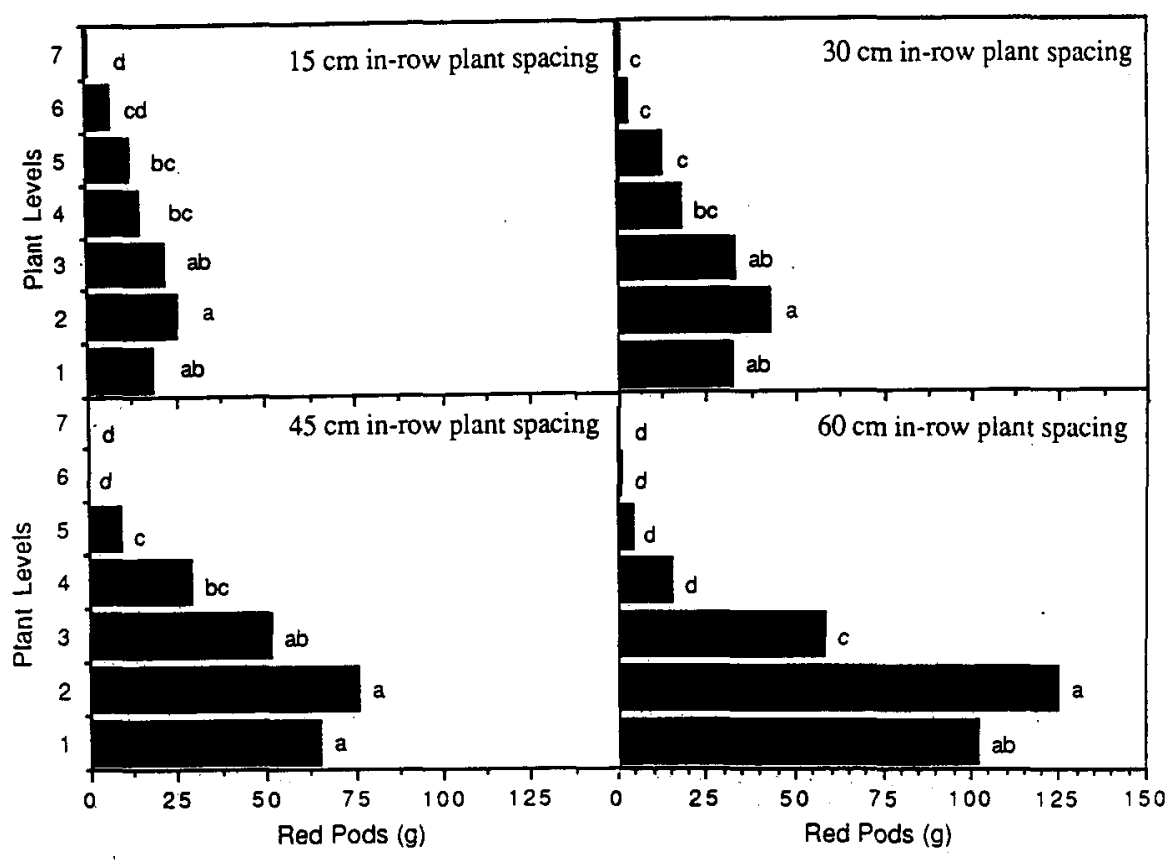

Fig. 1. Influence of in-row plant spacing on red-pod fresh weight distribution at various plant canopy levels, 1988. Plant levels were measured from the ground upward (see "Materials and Methods" section for details). Mean separation within in-row plant spacing treatments by LSD at $P \leq 0.05$.

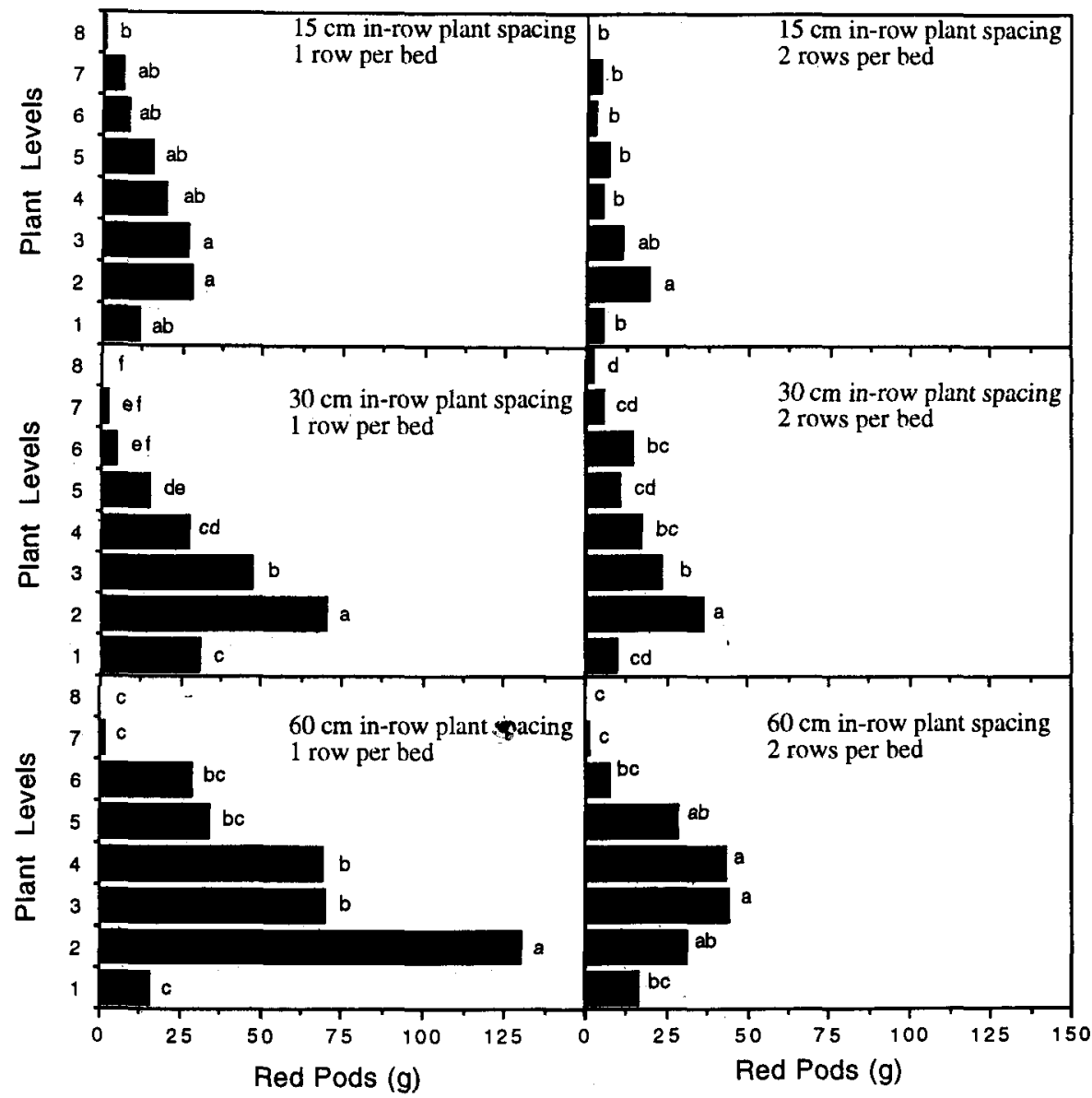

Fig. 2. Influence of in-row plant spacing and number of rows per bed on red-pod fresh weight distribution at various plant canopy levels, 1989. Plant levels were measured from the ground upward (see "Materials and Methods" section for details). Mean separation within in-row plant spacing and number of rows per bed treatments by LSD at $P \leq 0.05$. these factors may be important in determining optimum plant population density for harvesting cayenne peppers mechanically.

\section{Literature Cited}

Cook, W. P., R.P, Griffin, and C.E. Drye. 1982. Commercial pepper and eggplant production. Clemson Univ. Coop. Ext. Serv. Hort. Lflt. 35.

Johnson, J.R. and C.D. Johnson. 1992. Two zesty alternatives to bell peppers. Amer. Veg. Grower 40:24,26-27.

Kahn, B.A. 1992. Yield losses from delayed harvest of paprika pepper. HortScience 27:979-981.

Karlen, D. L., M.J. Kasperbauer, and J.P. Zublena. 1987. Row spacing effects on corn in southeastern U.S. J. Appl. Agr. Res. 2:65-73.

Knavel, D.E. 1977. The influence of nitrogen on pepper transplant growth and yielding potential of plants grown with different levels of soil nitrogen. J. Amer. Soc. Hort. Sci. 102:533-535.

Kovalchuck, S. 1983. A mechanical pepper harvester. Amer. Veg. Grower 31:8-9, 22.

Marshall, D.E. 1984. Horticultural requirements for mechanical pepper harvesting, p. 389-396. In: Proc. Intl. Symp. Fruit, Nut, and Vegetable Harvesting Mechanization, Bet Dagan, Israel, 5-12 Oct. 1983. Amer. Soc. Agr. Eng. Publ. 5-84.

McCraw, B.D. and J.K. Greig. 1986. Effect of transplant age and prunning procedure on yield and fruit-set of bell pepper. HortScience 21:430 431.

South, L. 1992. Ay, caramba! Mexican sauces outsell ketchup. Amer. Veg. Grower 40:30, 32.

Stofella, P.J. and H.H. Bryan. 1988. Plant population influences growth and yields of bell pepper. J. Amer. Soc. Hort. Sci. 113:835-839.

Sundstrom, F.J., C.H. Thomas, R.L. Edwards, and G.R. Baskins. 1984. Influence of $\mathrm{N}$ and plant spacing on mechanically harvested tabasco peppers. J. Amer. Soc. Hort. Sci. 109:642-645.

Weston, L. 1988. Effect of flat cell size, transplant age, and production site on growth and yield of pepper transplants. HortScience 23:709-711.

Wolf, I. and Y. Alper. 1984. Mechanization of paprika harvest, p. 265-275. In: Proc. Intl. Symp. Fruit, Nut, and Vegetable Harvesting Mechanization, Bet Dagan, Israel, 5-12 Oct. 1983. Amer. Soc. Agr. Eng, Publ. 5-84 